How to cite this article:

Hingun, M., \& Mohamed Nizamuddin, R. (2020). Incorporating article 31 bis flexibilities on trips public health into domestic Patent system: The inescapable way forward for Malaysia. Journal of International Studies, 16, 73-88. https://doi.org/10.32890/jis2020.16.5

\title{
Incorporating Article 31bis Flexibilities on Trips Public Health into Domestic Patent System: The Inescapable Way Forward for Malaysia
}

\author{
${ }^{1}$ Mohsin Hingun \& Rahamatthunnisa Mohamed Nizamuddin \\ Ahmad Ibrahim Kulliyah of Law, \\ International Islamic University of Malaysia,Malaysia

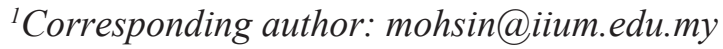

Received: 6/6/2020

Revised: 29/7/2020

Accepted: $11 / 8 / 2020$

Published: 30/12/2020

\begin{abstract}
The main purpose of this study is to highlight the absence of specific provisions on public health under Article 31 bis of the TRIPS Agreement that were not incorporated into the Patents Act 1983 in Malaysia. The main research question of this study is; why should Malaysia immediately amend its Patents Act 1983 to incorporate these flexibilities? Malaysia must develop effective strategies to implement policies, law and governance in managing the country's public health system. This is to ensure that the balance of rights between intellectual property owners and the public is maintained at all times. This study employs a qualitative research methodology that is based on primary sources such as the TRIPS Agreement and the Patents Act 1983, and is further supported by secondary sources such as journals and the contents of authorities' websites. This study is limited to the issues related to public health and patents. This study includes a discussion on the provisions related to patents and public health, proposed amendments to the Patents Act 1983 that should incorporate the provisions from Article $31 \mathrm{bis}$, and a conclusion was presented on the importance of immediately amending the Patent Act 1983 to incorporate these provisions, particularly during the current Covid-19 pandemic. This study proposes that the amendments must be made to Section 84 of the Patents Act 1983 with respect to Rights of Government, and not through the compulsory licence mechanism under Part X of the Patents Act 1983. Thus, this study concludes that currently, Malaysia is unable to implement the provisions under Article 31bis, unless the Patents Act 1983 is amended.
\end{abstract}

Keywords: Article 31bis, compulsory licence (CL), Patents Act 1983 (PA), public health flexibilities, TRIPS Agreement. 


\section{Introduction}

The Agreement on Trade-Related Aspects of Intellectual Property Rights $1994^{1}$ (TRIPS Agreement) was endorsed by members of the World Trade Organization (WTO), and continues to be an important international agreement that protects intellectual property rights in the current era. The TRIPS Agreement outlines the minimum standards of protection on intellectual property that has been acknowledged by member countries of the $\mathrm{WTO}^{2}$. After more than twenty years of its implementation, the TRIPS Agreement was recently amended when two-thirds of the WTO members accepted the Protocol Amending the TRIPS Agreement in 2017. The amendment included an addition of a new article i.e. Article 31 bis to endow public health flexibilities (WTO, n.d.) ${ }^{3}$ and WTO, 2005). The provisions of Article 31 bis enabled member countries to export production of pharmaceutical products under compulsory license (CL) to other countries, particularly to least-developed countries (LDCs) (United Nations Conference on Trade and Development, 2018). Prior to the TRIPS Agreement, this action was implemented via a 'waiver provision' that was introduced in the Doha Ministerial Declaration 2003 (WTO, 2003) ${ }^{4}$. Before the amendment, member countries of the TRIPS Agreement could only invoke CL under Article 31 for the purpose of using the patented product within the domestic market (Article 31(f) TRIPS Agreement, 1994) and could not be exported outside of the country ${ }^{5}$. With the addition of the new provision, member countries are permitted to export the production of a patented invention, however, limited to only pharmaceutical products through CL that is further compliant with certain regulations ${ }^{6}$. CL is granted to allow the 'infringement of a patent to be legal', and is subjected to certain guidelines that need to be fulfilled.

Malaysia is a member country of the TRIPS Agreement since its enforcement in 1995. The establishment of the Intellectual Property Legislation, under the Intellectual Property

1 Agreement on Trade-Related Aspects of Intellectual Property Rights 1994, came into effect on 1 January 1995. Malaysia became a member since 1 January 1995.

2 World Trade Organization. (n.d). Overview: the TRIPS Agreement. Retrieved July 18, 2019, from https:// www.wto.org /english/tratop_e/trips_e/intel2 e.htm.

3 World Trade Organization. (n.d.). TRIPS and public health. Retrieved July 18, 2019, from https://www.wto. org/english/tratop_e/trips_e/pharmpatent_e.htm.

$4 \quad$ World Trade Organization. (2003). Implementation of Paragraph 6 of the Doha Declaration on the TRIPS Agreement and public health. Retrieved November 18, 2019, from https://www.wto.org/english/tratop_e/ trips_e/implem_para6_e.htm. See also Gumble. M., (2008). Is Article 31bis enough - the need to promote economies of scale in the international compulsory licensing system. Temple International \& Comparative Law Journal, 22(1), 161-190, at 162-163 and 169-170 and Sperbeck, A.E. (2019) Mathematical solution to the sine of madness that is pharmaceutical compulsory licensing under the TRIPS Agreement and the Doha Declaration. Marquette Intellectual Property Law Review, 23(1), 21-56 at 32-42, on Doha Declaration that resulted in Article 31bis.

5 See Adekola, T.(2020). Regional mechanism under Doha paragraph 6 system - The largely untested alternative route for access to patented medicines. Asian Journal of WTO and International Law Health and Policy, 15(1), 61-90, for a better understanding on the situation before the introduction to Article 31bis and the situation after the implementation of the waiver provision by Rwanda.

6 An example of a formality to invoke these rights is through a submission of a notification to the TRIPS Council by both the EIC and the EMC, and must be provided when exercising these rights. 
Corporation of Malaysia Act $2002^{7}$ grants intellectual property rights. Hence, this is evidence that suggests Malaysia is a TRIPS-compliant country. Malaysia has incorporated the right to invoke the CL mechanism that was granted under Article 31 of the TRIPS Agreement into the Patents Act 1983 (PA) ${ }^{8}$, via two separate provisions; the CL mechanism under Part X of the PA, and the 'Rights of Government' (ROG) mechanism under Section 84 of the PA. Since the implementation of PA, Malaysia has invoked the ROG twice; in 2004 (Audrey, 2017) and 2017 (Cabinet Approves Compulsory Licence, 2017) that addressed the public health issues in the country. Thus far, the CL mechanism under Part X of the PA has yet to be invoked. However, as of June 2020, Malaysia is unable to implement the provisions of the new Article31bis of the TRIPS Agreement that allows the country to export any pharmaceutical products produced via the compulsory licensing flexibilities provided therein, as the PA has not yet adopted the new provisions that would allow Malaysia to exercise these public health flexibilities for export purposes. From the decision made in the case of Bato Bagi v Kerajaan Negeri Sarawak [2011] 6 MLJ 297, the court dictated that the international treaties themselves cannot be part of the Malaysian law, unless the provisions of these treaties have been incorporated into the local laws'. The case provided a compelling reason for Malaysia to incorporate the provisions of Article 31 bis into the PA that would enable Malaysia to exercise its rights as either an exporting member country (EMC) or an eligible importing country (EIC) (if necessary), in the event of a public health crisis in the country. As a country with manufacturing capabilities, Malaysia would be able to exercise its right as an EMC that could produce certain medications during a public health crisis, to assist LDCs when required. In addition, incorporating Article31bis would enable Malaysia to act as an EIC, in the event of a public health crisis in Malaysia. Malaysia is a developing country that has the ability to manufacture medicines by both original and generic manufacturers in the country. Malaysia must take immediate action to ensure that the PA incorporates the provisions of Article $31 \mathrm{bis}$, and subsequently bestows the responsibility to meet market demands, both as an EMC and EIC when the need arises. Malaysia must take into consideration its role as a potential EMC, especially since Malaysia is closer to many LDCs within ASEAN ${ }^{10}$ such as Cambodia, Laos and Myanmar, which are considered crucial EIC's (WTO, 2017) ${ }^{11}$.

Malaysia, as a developing country, should take the necessary steps to support these flexibilities of public health under Article 31bis through policy, law and governance. The advancement

The Intellectual Property Corporation of Malaysia Act 2002 defines Intellectual Property Legislation to consist of Trademarks Act 2019, Patents Act 1983, Copyright Act 1987, Industrial Designs Act 1996, LayoutDesigns of Integrated Circuits Act 2000, the Geographical Indications Act 2000 and all their respective subsidiary legislation.

8 Patents Act 1983, (Act 291), enforced October 1, 1986.

9 YA Raus Sharif FCJ clearly reiterated this issue.

10 ASEAN is the acronym for the Association of Southeast Asian Nations that consists of 10 countries, which are Malaysia, Indonesian, Singapore, Philippines, Thailand, Brunei, Vietnam, Laos, Myanmar and Cambodia.

11 World Trade Organization. (2017). Statement by Malaysia, 12 December 2017. $11^{\text {th }}$ WTO Ministerial Conference. Retrieved September 11, 2019, from https://www.wto.org/english/thewto_e/minist_e/mc11_e/ statements_e/mys_e.pdf. Malaysia gave its support to in respect of access to medicines, to both developing countries and LDCs. 
of developing countries would not only be beneficial domestically, but also internationally as the open trade system practised around the world would create an improving consumer market in all countries (Lee, 2016, p.461). Therefore, to ensure Malaysia continues to uphold good policies, law and governance, this study will examine Articles 31 and 31 bis of the TRIPS Agreement, as well as Part X and Section 84 of the PA to highlight Malaysia's inability to assist LDCs, as an EMC or act as an EIC in accordance to Article31bis, as no provisions have been added into the Malaysian law that grant this right. Moreover, this study aims at persuading the Malaysian Government to take important measures based on two recommendations; Malaysia must incorporate the provisions of Article 31 bis into the PA to address public health issues as soon as possible particularly during this Covid-19 pandemic situation; and to incorporate the provisions of Article 31 bis into PA by using ROG and not CL, since there exist two types of rights; namely the CL mechanism in the PA under Part X, and the ROG mechanism under Section 84. This study addresses the related provisions in the TRIPS Agreement on public health with respect to patent, and will be cross referenced with related provisions in the PA. Subsequently, the issues surrounding public health, particularly with regards to other types of intellectual property such as trade mark, will not be addressed herein.

\section{Methodology}

This study employed a doctrinal legal research methodology that aims to examine the current legal system adopted by Malaysia with respect to the CL mechanism that is required to be established in accordance to the TRIPS Agreement. The study was purely librarybased research, where the main source of research are from primary sources such as the TRIPS Agreement and the PA, and is further supported by secondary sources such as journals and websites of authorities. It is important to review the websites of authorities as the issue of public health flexibilities under Article 31 bis is relatively new, and was inserted into the TRIPS Agreement only in 2017. Furthermore, there is no law in Malaysia that has incorporated the provisions on these public health flexibilities; thus, a proposal of an appropriate action to be taken by the Malaysian Government when attending to the insertion of the relevant legal provisions into the PA. Additionally, this study is theoretical, analytical and exploratory. The study provides an examination of the theoretical aspects of the provisions of Articles 31 and 31bis TRIPS Agreement and cross reference these provisions to the PA, an analysis on the importance of incorporating the provisions of Article 31 bis on public health flexibilities into the PA immediately, and finally, highlighting the importance to the Malaysian Government on the public health flexibilities provisions in pursuant to Article 31 bis that must be incorporated into the PA, through ROG.

\section{Discussion}

\section{TRIPS and Public Health Related Provisions of Patents}

Members of the TRIPS Agreement intended to "reduce distortions and impediments to international trade and to ensure that intellectual property rights do not become barriers to 
legitimate trade" (Preamble, TRIPS Agreement, 1994), and subsequently granted special needs to the LDCs that provided maximum flexibility in the implementation of their domestic laws ${ }^{12}$. Article 8 of the TRIPS Agreement stipulates that member countries have the right to adopt the measures necessary to protect public health. Paragraphs 5 and 6 of the Preamble elucidate the underlying concepts of the Article, and dictate that member countries may take specific actions to protect public health by adopting measures against any abuse of intellectual property rights (Gervais, 2008, p.209). CL is one of the mechanisms adopted by member countries to address this issue. According to Ford (2007, p.945). CL is a licence issued by a government to a third party allowing for the "infringement" of a patented invention, and at the same time, ensures that the patentee is adequately compensated. Although the TRIPS Agreement permits CL to be exercised legally, however, the mechanism is often labelled as theft of intellectual property (Bagley, 2018, p.2467). Nevertheless, the protection of public health issues for legitimate reason that is based on the TRIPS Agreement is indeed justifiable, on grounds of good faith (Manu, 2016, p.92).

It is vital for Malaysians, especially Government officials, to understand the concept of intellectual property and the protection mechanisms under the TRIPS Agreement to ensure that the balance of rights between the owners of the intellectual property and the public are maintained and protected at all times. This can only be achieved through knowledge on intellectual property matters. Though Malaysia is a TRIPS compliant country, there still seem to be a lack of knowledge on intellectual property matters within the public. This is evident from the lack of respect for intellectual property in Malaysia (Ratnaria \& Ida Madieha, 2012). Once a better understanding of intellectual property matters is achieved, the concept of balance of rights and the importance of issues relating to public health, would be more appreciated. In assessing the balance of rights between patent owners and the public, with regards to public health issues, the provisions of Articles 31 and 31 bis of the TRIPS Agreement that addresses the CL mechanism need to be examined.

\section{Article 31 of the TRIPS Agreement}

Article 31 as per its title "Other Use Without Authorization of the Right Holder", provides that member countries are permitted to incorporate the provision in their laws which allows "the use of a patented invention, without the permission of the patentee", under stringent rules. The government or other parties authorized by the government are authorized to invoke such a right, for which such a right, is subjected to certain rules (Desai, 2016, pp.34-43). When considering public health issues, the provisions of this Article should be exercised in good faith to promote the access to medicine, and not act as a barrier to lower the prices of medicine (Kim, 2016, p.84). Article 31 permits member countries to establish this system independently, and encourages member countries to build and incorporate such a system into their laws. This is observed in the Article states that "Where the law of a Member allows for other use of the subject matter of a patent without the authorization of the right holder". Article 31 is commonly referred to as the "CL provision" (Effingham,

12 Preamble to the TRIPS Agreement. 
2016, p.884; WTO, n.d. ${ }^{13}$; World Health Organization [WHO], n.d. ${ }^{14}$ ). This terminology is commonly used to address the issues under Article 31, and was constructed exclusively to include the provisions that pertains to CL, i.e. the use without authorization of the patent owner (Raducanu, 2011) ${ }^{15}$. However, the term 'CL' does not appear in the provisions of Article 31, although the terminology does appear in the TRIPS Agreement under Article 21, in the section that pertains to trademarks ${ }^{16}$.

For the purposes of this study, within the Malaysian context, Article 31 was incorporated into the PA, whereby references were made to two different rights, which are CL and ROG. It is important to distinguish between the two rights as they grant different flexibilities and is dependent on the reasons for such rights to be invoked. It is crucial to note the differences between CL and ROG in Malaysia as the Malaysian public and international parties have mistakenly considered CL as the right granted to access medicine that was invoked by the Malaysian Government previously (Loh, 2018; Chee, 2019; William, 2019), and not pursuant to the ROG. ROG can also be referred to as 'government-use licence', a terminology used by some countries where the government invokes this right during a national emergency or public health crisis (Kyung Bok, 2019, p.1). The CL and ROG mechanisms are tools to maintain the balance of rights between patent owners and the public, mainly for issues surrounding public health matters.

\section{Article 31 bis of the TRIPS Agreement}

Article 31 bis was derived from the Doha Declaration $2001^{17}$ that depicts the underlying provisions of the "Paragraph 6 system", where this system was intended to help poorer countries in gaining easier access to medicines (Alsegard, 2004). Article 31 bis was initially proposed by the African countries (Kongolo, 2003, p.374), and was agreed upon by other member countries when they realized that the system introduced under Article 31 could not be applied by member countries that had 'insufficient or no manufacturing capacity' to produce medicines. Member countries agreed on the need to provide other options to governments when addressing public health needs, via certain flexibilities (WTO, n.d.) $)^{18}$. Therefore, these flexibilities, under the new provision, have allowed governments to import medicines produced in other countries to address a public health crisis. In addition to the rights granted by Article 31, EIC and other member countries could export medicines produced by countries considered as $\mathrm{EMC}^{19}$. However, since Article 31(f) states that the

13 World Trade Organization. (n.d.). Compulsory licensing of pharmaceuticals and TRIPS. Retrieved July 22, 2019, from https://www.wto.org/english/tratop_e/trips_e/public health faq e.htm.

14 World Health Organization. (n.d). The Doha Declaration on the TRIPS Agreement and public health. Retrieved July 22, 2019, from https:/www.who.int/medicines/areas/policy/policy/doha_declaration/en/.

15 The author refers to compulsory license as "a license granted by an administrative body upon, application, to a third party to exploit an invention without the consent of the patent owner".

16 The term CL, in relation to patents, only appears in Article 31 bis after its enforcement in January $23,2017$. Article 31 on patents does not provide any reference to the term CL till today.

17 Doha WTO Ministerial Declaration on TRIPS and Public Health, adopted in November 2001.

18 World Trade Organization. (n.d.). TRIPS and public health. Retrieved July 22, 2019, from https://www.wto. org/english/tratop_e/trips_e/pharmpatent_e.htm.

19 IWTO Analytical Index. (n.d.). Article $31 \bar{b}$ is and the Annex to the TRIPS Agreement. Retrieved September 3, 2019, from https://www.wto.org/english/res_e/publications_e/ai17_e/trips_art31_bis_oth.pdf. 
invocation of the rights under Article 31 is "predominantly for the supply to domestic market of the member country", Article 31bis was introduced to expand on the provisions of Article 31(f) that grants the right for the exploitation of the patents, in pursuant to Article 31, for the manufacturing of pharmaceutical products to address a public health crisis in an EIC.

Unlike Article 31, Article 31 bis does provide references to CL and appears numerous times in the Article itself, and in the Annex to the TRIPS Agreement. Moreover, Article 31 bis provides clear definitions of the terminologies used in the agreement such as pharmaceutical products, EIC and EMC. The provisions also include the procedures that is required to be taken by member countries for the implementation of the system described under Article 31 bis. Article 31 bis provides clear references that specifically addresses pharmaceutical products only, and does not include other products. Pharmaceutical product is defined in the Annex to the TRIPS Agreement as "any patented product, or product manufactured through a patented process, of the pharmaceutical sector needed to address the public health problems such as HIV/AIDS, tuberculosis and malaria and it includes diagnostic kits needed for such treatment" 20 . The first country to have invoked the Paragraph 6 system as an EIC is Rwanda, (International Centre for Trade, 2007), while the first country to have invoked the Paragraph 6 system as an EMC is Canada (WTO, 2007). The Paragraph 6 system is now no longer applicable with the enforcement of Article 31bis in January 2017 that incorporated and expanded this system. Article31bis and the Annex to the TRIPS Agreement addresses the following issues:-

(i) issuance of a CL, with respect to a pharmaceutical product produced by an EMC, can only be granted if a public health problem is present in an EIC;

(ii) the EMC shall pay the patentee adequate remuneration for the invocation of this right;

(iii) LDCs are automatically categorized as an EIC, and for any other country wishing to be categorized as an EIC, are obliged to submit a notification to the Council for TRIPS;

(iv) to invoke Article $31 \mathrm{bis}$, the EIC is obliged to provide a notification to the Council for TRIPS on its intentions and specify the details such as its capacity, quantity and name of pharmaceutical product; and

(v) to invoke Article $31 \mathrm{bis}$, the EMC is obliged to provide a notification to the Council for TRIPS, for the purpose of obtaining CL that includes the details on the licence such as name of licensee, name of product, name of EIC and the duration for the licence.

\section{Malaysian Patents Act 1983}

The PAwas established to govern matters relating to patents in Malaysia. It is a comprehensive statute that deals with patent matters in Malaysia, and includes the provisions of Article 31 that is highlighted in Part X and Section 84 of the PA. However, the provisions of Article

\footnotetext{
$20 \quad$ World Trade Organization. (n.d.). Paragraph 1 and 5 of Declaration on the TRIPS Agreement and public health, WT/MIN(01)/DEC/2. Retrieved September 3, 2019, from https://www.wto.org/english/thewto_e/ minist_e/min01_e/mindecl_trips_e.pdf provides a list of public health problems.
} 
31 bis is yet to be incorporated into the PA. This is underlined in both Part X and Section 84 of the PA that only addresses the issue of "predominantly for the supply of domestic market", without any provisions allowing for export. In addition, there are no other provisions within the PA that suggest the use "without authorization of patent owner" for the purpose of exportation. Part X and Section 84 of the PA will be discussed in the following sections.

\section{Part $X$ of the $P A$}

Part X of the PA is titled "Compulsory Licence", and comprises Sections $48-54$. CL is defined in Section 48 as "the authorization to perform in Malaysia without the agreement of the owner of the patent in respect of the patented invention, any actions relating to the exploitation of a patented patent". Part X states that "at any time after 3 years from the grant of a patent or 4 years from the filing date of a patent application", any person may apply for a CL, if there is "no production of the patented product in Malaysia without any legitimate reason or if there is no sale of the patented product in Malaysia or if there are some, but they are sold at unreasonably high prices or do not meet public demand without legitimate reasons". The provisions in Part X though is adapted from Article 5 Paris Convention ${ }^{21}$, are nevertheless in line with Article 31 TRIPS Agreement in particular to Section 53 which clearly emphasizes that the CL shall be limited "for the purpose of supply of the patented invention predominantly in Malaysia". Furthermore, during the application to obtain a CL in Malaysia, an application can be made by any person to the Registrar of Patents of the Patent Registration Office ${ }^{22}$, and the approval for a CL will be granted by the Intellectual Property Corporation of Malaysia (MyIPO).

\section{Section 84 of the PA}

Section 84 is titled "Rights of Government" and it provides inter alia that the Minister responsible for intellectual property matters in Malaysia i.e. currently, the Minister of Domestic Trade and Consumer Affairs (DTCA), may decide without the agreement of the patent owner to exploit the patented invention, in the event the Malaysian Government deems there to be a situation of "a national emergency or public interest issues such as national security, nutrition and health" in Malaysia. Before determining the scope of exploitation upon the invocation of this right, the Ministry will have to notify the patent owner as it is within his right, and would pay the patentee an adequate remuneration. Section 84 clearly states that the exploitation of a patent, pursuant to the ROG, shall predominantly be for the supply to the Malaysian market. For ROG to be invoked, the Malaysian Government must first determine a situation which qualifies as a "national emergency" or "a public interest issue" that would permit the Ministry of DTCA to invoke ROG for the exploitation of a patented invention. At present, the "Malaysian Government's assessment of a public health issue" is determined by the Ministry of Health $(\mathrm{MOH})$ that proposes to the Cabinet on

${ }_{21}$ Paris Convention for the Protection of Industrial Property 1883 (as amended on September 28, 1979), entered into force on June 3, 1984. It is the very first international treaty in respect of industrial property.

The Patent Registration Office operates under the administration of the Intellectual Property Corporation of Malaysia. 
the existence of a public health crisis in Malaysia and that there is an insufficiency of the existing medical supplies to address the crisis. Once the Cabinet determines that there is such a crisis, the Ministry of DTCA would then be authorized to invoke ROG.

\section{Invocation of CL and ROG under the PA}

Since the enforcement of PA on October 1, 1986, there has not been any reported cases of CL application under Part X of the PA. However, Malaysia had exercised its rights that was granted under Section 84 of the PA by invoking ROG, on grounds of public health, twice since the introduction of PA (Third World Network, 2017). The first time ROG was invoked was in 2004 for the importation of antiretroviral drugs to treat HIV infections (Audrey, 2017). Subsequently, ROG was invoked again in 2017 for the generic medication of Sofosbuvir that treated Hepatitis C (Cabinet Approves Compulsory Licence, 2017). Malaysia's bold action in invoking ROG on grounds of public health in the country had earned recognition from the world and was awarded the "Leadership Award in Intellectual Property and Access to Medicines" in 2018, during the "Global Summit of Intellectual Property and Access to Medicines" in Morocco (Loh, 2018). This highlights Malaysia's emphasise on the protection of its citizens' healthcare and interest, and responsibly invoked this right that ensured a fair and balance of rights between patent owners and the public.

\section{Recommendations}

\section{Importance of Immediately Incorporating Article 31bis into the PA}

From the above, it is seen that Malaysia's fame has only benefitted itself and has left the LDCs, especially those less fortunate members of ASEAN, helpless, as Malaysia, being a developing country with manufacturing capacity to manufacture and produce pharmaceutical products, currently cannot export pharmaceutical products under the public health flexibilities provided by Article 31bis. As a member of the ASEAN, Malaysia continues to play a vital role in the region for all aspects. If a LDC ASEAN member country seeks Malaysia's assistance to produce medicines for exportation pursuant to Article 31 bis TRIPS Agreement, such assistance could not be provided as there are no provisions in the PA that would legally allow Malaysia to render its services. The exportation of pharmaceutical products to LDCs, particularly to countries in ASEAN, would reflect Malaysia's propensity towards shared economic growth, social progress and cultural development across the region. Every human around the world has the right to health care, and this includes access to medicines (Dickhut, 2017, p.216).

The crux of Paragraph 6 system, as embodied in Article 31bis, is to facilitate the exportation of the pharmaceutical product from a country with manufacturing capabilities i.e. the EMC, to a country, without or with insufficient manufacturing capabilities i.e. the EIC. The EIC, has no other obligation under this system except to provide a notification to the 
Council for TRIPS of its importation from the EMC. There is no doubt that even without incorporating Article 31 bis into the PA, Malaysia can still import pharmaceutical products from other countries (Audrey, 2017) based on the provisions of Section 84 PA, but still, without a provision incorporating Article 31bis, Malaysia may find difficulties when importing from countries where there is an existing patent over the pharmaceutical product. This is particularly with respect to the issue on remuneration that is required to be paid to the patent owner, because Section 84(3) PA requires Malaysia to pay the patent owner in Malaysia, whereas the use of public health flexibilities under Article 31bis, paragraph (3) provides that there is no need for the EIC to pay remuneration to the patent owner in the event remuneration is paid in the EMC. There might be a time when Malaysia may need to import pharmaceutical products from other countries, especially with the evolution of new technologies and artificial intelligence around the world and particularly during this Covid-19 pandemic situation. Without a provision in the PA incorporating the public health flexibilities provided under Article 31 bis, Malaysia may incur a loss.

There is little doubt that Malaysia is capable of implementing effective strategies through various policies, law and governance when managing the country, particularly with respect to public health issues. Moreover, Malaysia is adept at ensuring and maintaining the balance of rights between intellectual property owners and the public at all times. However, such strategies that include the policies, law and governance, should also be implemented for the shared benefits with other countries, especially among member countries of ASEAN. The shared responsibilities between Malaysia and other members of the ASEAN necessitates the incorporation of Article31bis into the PA. Countries with manufacturing capabilities, must help the low and middle income countries without manufacturing capabilities, so that the rich countries do not oppress them using bilateral agreements (Ooms \& Hanefeld, 2019).

\section{Proposed Amendments to Malaysian Patents Act 1983}

At the time of writing this study, MyIPO had uploaded a consultation paper that pertains to the possible amendment of the PA (MyIPO, 2019) ${ }^{23}$. Although it is congenial to note that Malaysia has finally looked into this matter, it is submitted that "grant of compulsory licence" (a terminology which exists under Part X PA) is not the solution to incorporating the public health flexibilities under Article 31bis. Grant of CL under Part X PA is inappropriate for purposes of Article 31bis, as in Malaysia, the right to grant a CL is envisaged with MyIPO whereas the right to invoke ROG on issues related to public interests is vested with the Malaysian Government. It is submitted that CL is not the appropriate mechanism for the incorporation of Article 31bis into the PA, as CL is granted based on the Paris Convention's basic requirement that an application be made only " 3 years after the grant of the patent or 4 years after the filing of the patent". Since issues of public health are of utmost importance

23 The Intellectual Property Corporation of Malaysia. (2019). Consultation Paper: Proposed amendments to the Patents Act 1983. Retrieved September 10, 2019, from https://drive.google.com/file/d/1PYTxbQS3knu jgKC7K0nE6Pp8VT71cKYb/view. The consultation period for this paper was from August 30, 2019 until September 13, 2019. 
to public, this basic rule would hamper the ultimate purpose of Article31bis. An immediate action taken by the Malaysian Government as per that provided under Section 84 PA would be more appropriate to deal with issues of public health.

This study asserts that MyIPO is not a competent authority to deal with matters that involve international sovereign systems, such as the Paragraph 6 system that requires the involvement of the Council for TRIPS, under the WTO. The Council for TRIPS is the regulatory body responsible for administering the TRIPS Agreement (WTO, n.d. $)^{24}$. In Malaysia, WTO related matters are dealt with by the Ministry of International Trade and Industry (MITI) ${ }^{25}$. As the Paragraph 6 system requires dealings with WTO, it is proposed that the Malaysian Government is the appropriate proxy to deal with the Council for TRIPS, and not MyIPO. The Malaysian Government may liaise with the Council for TRIPS through MITI, MOH or the Ministry of Foreign Affairs (MOFA) as they are in a position of authority to know the status of an EIC on public health issues and the dealings with the Council for TRIPS. Moreover, this study strongly proposes that Article 31 bis be rightfully incorporated into the PA as ROG, and not CL. The rights under Article 31bis should only be exercised between the sovereign authorities of one country with another country as emphasized by Paragraph 2 Annex to the TRIPS Agreement, which states that member countries that implement this system are obligated to notify the Council for TRIPS accordingly. Since MyIPO does not deal with the WTO and all matters that relates to the WTO are handled by the Malaysian Government, it is argued that MyIPO merely acts a statutory body, and hence, is not the appropriate regulatory body to exercise these rights. Though, the notification system required under Article 31 bis does not require an approval from the Council for TRIPS, the issues involving global public health matters should be dealt by the governments of their respective countries.

The first country to have invoked the rights for the flexibilities provided under Paragraph 6 system was Rwanda in 2007, when it made a request to the Canadian Government for the exportation of HIV/AIDS drugs (Jiang, 2019, p.480). This system allowed the export of the drug via the waiver provision under Paragraph 6 that was incorporated into "Canada's Access to Medicines Regime" (Government of Canada, 2015), and operated via a CL system that was similar to the current CL system practiced in Malaysia under Part X. The application for CL in Canada was made to the Commissioner of Patents. However, this mechanism was argued by Houston and Beall $(2018$, p.235) and was considered a failure as the system was never invoked in Canada ever since. Although Goodwin (2008, p.570) suggested that the mechanism itself had failed, there were no indication that it was caused by either CL or ROG. As the system implemented by the Canadian Intellectual Property Office had failed, this clearly implies that Malaysia should immediately incorporate the provisions of Article 31bis into the PA through ROG, and to learn the lessons from previous

${ }_{24}$ World Trade Organization. (n.d.). Council For TRIPS. Retrieved September 13, 2019, from https://www. wto.org/english/tratop_e/trips_e/ intel6_e.htm.

25 Ministry of International Trade and Industry. Retrieved September 13, 2019, from www.miti.gov.my whereby WTO matters including TRIPS Agreement are specified as being within the purview of MITI. 
experiences to ensure the effectiveness of implementing the system in Malaysia and other countries around the world. Therefore, such rights should be placed with the Malaysian Government, and not with a statutory body.

MyIPO is merely a statutory body that grants protection, and oversees intellectual property matters in Malaysia (Intellectual Property Corporation of Malaysia Act 2002) ${ }^{26}$. While the issuance of a CL is within the jurisdiction of MyIPO's, granting of CL on grounds of public health issues faced by other member countries of the TRIPS Agreement by MyIPO is not appropriate, given the status of MyIPO as a statutory body and its capability of verifying such public crisis information of other countries. Such matters should be within the jurisdiction and authority of the relevant ministries under the Malaysian Government, i.e. MITI or MOH or MOFA. A government-to-government relationship would ensure the issues related to public health that is faced by one government, could be resolved with the help of another government through a contracted agreement signed between both parties. This would eliminate the issues of abuse of power from either countries, and would subsequently lead to progressive cooperation. MyIPO is a statutory body, and therefore, it is not a suitable proxy to assure the authenticity of the documents submitted by a third party for the purpose of invoking the flexibilities under Article 31 bis. In addition, the issue of adequate remuneration, under Article 31 of the TRIPS Agreement, has been shrouded with ambiguity till present. The TRIPS Agreement does not provide specific guidelines on the adequate remuneration that should be bestowed to the patent owner. Similarly, Article 31 bis does not specify any provisions on the adequate remuneration to the patent owner. As these issues are flawed, further interpretations within the provisions, the government maintains a stronger position to determine the authenticity of documentation and necessary remuneration for all parties; the government, patent owner and general public, for which all will benefit from the invocation of these rights (Nuno, 2016, p.411). While the government takes responsibility to oversee the system, the unnecessary misuse of the public health flexibilities under Article 31 bis will surely be avoided. In view of that, it is strongly suggested that the public health flexibilities under Article 31 bis be incorporated into the PA under the ROG system, and not under the CL system.

\section{Conclusion}

Although Article 31 bis was enforced in January 2017, its origin dates back to 2001. The provisions of Article 31 bis grants the right of LDCs to obtain easier access to medicines. The concept of intellectual property rights must be balanced by the government of each country, so as to benefit its public as well. Malaysia must incorporate the public health flexibilities provided in Article 31 bis into the PA so that not only Malaysians can benefit from these flexibilities, but also LDCs and other countries with no manufacturing capabilities of pharmaceutical products, particularly the LDCs in ASEAN. Malaysia should continue to amend and improve its laws by incorporating the necessary provisions of Article 31 bis

$26 \quad$ Intellectual Property Corporation of Malaysia Act 2002, (Act 617), enforced on March 3, 2003. 
under the ROG system, instead of the CL mechanism. In Paragraph 3 and 4 of the Annex to the TRIPS Agreement, Article 31 bis states that member countries should exercise caution on the potential misuse of the system that may arise from these public health flexibilities. This study concludes that the Malaysian Government should take immediate action and adopt the public health flexibilities under Article 31 bis of the TRIPS Agreement by incorporating these flexibilities under the ROG system, and not through CL system, into the PA. This recommendation is substantiated, and is further supported for the protection of national sovereignty, where the Malaysian Government is fully responsible for its public health issues within its own country. Moreover, it is important for the Malaysian Government to extend this right by incorporating Article 31 bis under the ROG to ensure that other countries that are least developed will be able to benefit from the assistance that can be provided by Malaysia. ROG is indeed the appropriate mechanism to embody the provisions of Article 31 bis. An amended proposal of Section 84 of the PA was drafted and was studied extensively in a separate article by Mohsin and Rahamatthunnisa, (2020) that could be further explored, and used as guidance. Hence, this study proves the need for Malaysia to step up its efforts in amending the PA by incorporating Article 31bis that ensures a balance of rights between patent owner and the public, and establish Malaysia's position at the forefront of public health initiatives, more so ever in the current Covid-19 pandemic situation.

\section{References}

Adam Aziz. (2019, February 09). Malaysia drops four spots to $23^{\text {rd }}$ place in global IP protection. The Edge Market. Retrieved September 10, 2019, from https://www. theedgemarkets.com/article/malaysia-drops-four-spots-23rd-place-global-ipprotection- 0 .

Adekola, T. (2020). Regional mechanism under Doha paragraph 6 system - The largely untested alternative route for access to patented medicines. Asian Journal of WTO and International Law Health and Policy, 15(1), 61-90.

Agreement on Trade-Related Aspects of Intellectual Property Rights 1994.

Alsegard, Erik. (2004). Global pharmaceutical patents after the Doha Declaration - What lies in the future. SCRIPTed: A Journal of Law, Technology and Society, 12, 12-45.

Audrey Edwards. (2017, April 20). Rights to drugs sought. The Star Online. Retrieved September 10, 2019, from The Star Online: https://www.thestar.com.my/news/nation/ 2007/04/20/rights-to-drugs-sought.

Bagley, M. A. (2018). The morality of compulsory licencing as an access to medicines tool. Minnesota Law Review, 102(6), 2463-2496.

Chee Yoke Ling. (2019, March 09). Using compulsory licence for affordable medicines. Astro Awani. Retrieved September 09, 2019, from Astro Awani http://english. astroawani.com/ malaysia-news/using-compulsory-licence-affordable-medicines-200558.

Copyright Act 1987 (Act 332).

Desai, Manisha. A. (2016). Compulsory licensing: Procedural requirements under the TRIPS Agreement. Pharmaceutical Policies \& Law, 18(1-4), 31-44. 
Doha WTO Ministerial Declaration on TRIPS and Public Health 2001.

Dickhut, Sarah M. (2017). Ethical and procedural barriers to accessing critical medicines in least developed countries: A look at TRIPS and the Doha Documents. Journal of Gender, Race and Justice, 20(1), 209-235.

Effingham, Ann Marie, (2016). TRIPS Agreement Article 31(b): The need for revision. Seton Hall Law Review, 46(3), 883-909.

Ford, S. M. (2000). Compulsory licensing provisions under the TRIPs Agreement: Balancing pills and patents. American University International Law Review, 15(4), 941-974.

Geographical Indications Act 2000 (Act 602).

Gervais, Daniel. (2008). The TRIPS Agreement - Drafting history and analysis (3 ${ }^{\text {rd }}$ ed.). Sweet \& Maxwell: Thomson Reuters (Legal) Limited.

Goodwin, P. E. (2008). Right idea, wrong result - Canada's access to medicines regime. American Journal of Law \& Medicine, 34(3), 567-584.

Government of Canada. (2015). Canada's access to medicines regime. Retrieved November 20, 2019 from https://www.canada.ca/en/health-canada/services/canada-accessmedicines-regime.html.

Gumble. M., (2008). Is Article 31bis enough - the need to promote economies of scale in the international compulsory licensing system. Temple International \& Comparative Law Journal, 22(1), 161-190, at 162-163.

Houston, A. R.; Beall, R. F. (2018). Could the paragraph compulsory licence system be revised to increase participation by the generics industry: Lessons learned from unheralded and unsuccessful attempt to use Canada's access to medicines regime. McGill Journal of Law and Health, 12, 227-246.

Industrial Designs Act 1996 (Act 552).

Intellectual Property Corporation of Malaysia Act 2002 (Act 617).

International Trade for Sustainable and Development. (2007). Rwanda becomes first country to try to use WTO procedure to import patented HIV/Aids drugs. Bridges, 11(27). Retrieved November 18, 2019 from https://www.ictsd.org/bridges-news/bridges/ news/rwanda-becomes-first-country-to-try-to-use-wto-procedure-to-import.

Jiang, C. (2019). Who is the God of medicines - Deciphering China's stance on pharmaceutical compulsory licensing. Asian Journal of WTO and International Health Law and Policy, 14(2), 471-524.

Kim, D.D. (2016). Voluntary licensing of pharmaceuticals: The strategy against compulsory licensing. American University Intellectual Property Brief, 8(1), 63-[vi].

Kongolo, Tshimanga. (2003). TRIPS, the Doha Declaration and public health. Journal of World Intellectual Property, 6(2), 373-378.

Kyung-Bok Son. (2019). Importance of intellectual property system in attempting compulsory licensing of pharmaceuticals: A cross-sectional analysis. BMC, Globalization and Health, 15, 42. Retrieved October 08, 2019 from MEDLINE Complete Database https://doi.org/10.1186/s12992-019-0485-7.

Layout-Designs of Integrated Circuits Act 2000 (Act 601).

Loh Foon Fong. (2018, January 19). Malaysia awarded for gutsy move. The Star Online. Retrieved September 10, 2019 from The Star Online: https://www.thestar.com. my/news/nation/2018/01/19/malaysia-awarded-for-gutsy-move-govt-invokescompulsory-licensing-for-affordable-hepatitis-c-medicin. 
Manu, T. (2016). Interpreting the doctrine of legitimate expectations in WTO jurisprudence in its application to compulsory licenses. Trade, Law and Development, 8(1), 63-ii.

Mohsin Hingun \& Rahamatthunnisa Mohamed Nizamuddin. (July 2020). Amending Section 84 Patents Act 1983 to encompass the health flexibilities leverage accorded by Article 31 bis TRIPS Agreement. UUM Journal of Legal Studies, 11(2).

Ministry of International Trade and Industry. Retrieved September 13, 2019, from www. miti.gov.my.

Nuno, M. (2016). A fair return approach to pharmaceutical compulsory licensing. Case Western Reserve Journal of International Law, 48(2), 395-416.

Ooms, Gorik., \& Hanefield, Johanna. (2019). Threat of compulsory licences could increase access to essential medicines. BMJ, 365. Retrieved September 10, 2019, https://doi. org/10.1136/bmj.12098.

Paris Convention for the Protection of Industrial Property 1883 (as amended on September 28, 1979).

Patents Act 1983 (Act 291).

Raducanu, Adina. (2011). Who is afraid of compulsory licences. USAK Yearbook of International Policy \& Law, 4, 255-288.

Ratnaria Wahid., \& Ida Madieha Abdul Gjani Azmi. (2012). Comparative study on copyright exception for teaching purposes: Australia, Malaysia and the United Kingdom. Journal of International Studies, 8, 31-45.

Sperbeck, A. E. (2019) Mathematical solution to the sine of madness that is pharmaceutical compulsory licensing under the TRIPS Agreement and the Doha Declaration. Marquette Intellectual Property Law Review, 23(1), 21-56.

The Intellectual Property Corporation of Malaysia. (2019). Consultation Paper: Proposed amendments to the Patents Act 1983. Retrieved September 10, 2019, from https:// drive.google.com/file/d/1PYTxbQS3knujgKC7K0nE6Pp8VT71cKYb/view.

The Malay Mail. (2017, September 14). Report: Cabinet approves compulsory licence for Hepatitis C generics. Retrieved September 10, 2019, from The Malay Mail: https:/www.malaymail.com/news/malaysia/2017/09/14/report-cabinet-approvescompulsory-license-for-hepatitis-c-generics/1464619

Third World Network. (2017, November 3). Sharing national experiences in use of compulsory licences. Retrieved September 10, 2019, from https://www.twn.my/ title2/intellectual_property/info.service/2017/ip171102.htm.

Trademarks Act 2019 (Act 815).

United Nations Conference on Trade and Development. (2018, November 20). What are the least developed countries. UNCTAD/PRESS /IN/2018/008, Geneva, Switzerland. Retrieved July 18, 2019, from https:/unctad.org/en/pages/PressRelease.aspx ?OriginalVersionID $=486$.

William New. (2019, February 02). Malaysia still under pressure to make Hepatitis C medicine more expensive. Intellectual Property Watch. Retrieved September 11, 2019, from Intellectual Property Watch https:/www.ip-watch.org/2019/02/13/malaysiastill-pressure-make-hepatitis-c-medicine-expensive/.

World Health Organization. (n.d). The Doha Declaration on the TRIPS Agreement and public health. Retrieved July 22, 2019, from https:/www.who.int/medicines/areas/ policy/policy/doha_declaration/en/. 
World Trade Organization. (2005). Amendment of the TRIPS Agreement. Retrieved July 18, 2019, from https://www.wto.org/english/tratop_e/trips_e/wtl641_e.htm.

World Trade Organization. (2007) Canada is first to notify compulsory licence to export generic drug. Retrieved July 1, 2020 from https://www.wto.org/english/news_e/ news07 e/trips health notif oct07 e.htm.

World Trade Örganization. (n.d.). Compulsory licensing of pharmaceuticals and TRIPS. Retrieved July 22, 2019, from https:/www.wto.org/english/tratop_e/trips_e/public_ health_faq_e.htm..

World Trade Organization. (n.d). Council for TRIPS. Retrieved September 13, 2019, from https://www.wto.org/english/tratop_e/trips_e/ intel6_e.htm.

World Trade Organization. (2003). Implementation of Paragraph 6 of the Doha Declaration on the TRIPS Agreement and public health. Retrieved November 18, 2019, from https://www.wto.org/english/tratop_e/trips_e/implem_para6_e.htm.

World Trade Organization. (n.d). Overview: the TRIPS Agreement. Retrieved July 18, 2019 , from https://www.wto.org/english/tratop_e/trips_e/intel2 e.htm.

World Trade Organization. (n.d). Declaration on the TRIPS Agreement and Public Health, WT/MIN(01)/DEC/2. Retrieved September 3, 2019, from https:/www.wto.org/ english/thewto_e/minist_e/min01_e/mindecl_trips_e.pdf.

World Trade Organization. (2017). Statement by Malaysia, 12 December 2017. $11^{\text {th }}$ WTO Ministerial Conference. Retrieved September, 11, 2019, from https:/www.wto.org/ english/thewto_e/minist_e/mc11_e/statements_e/mys_e.pdf.

World Trade Organization. (n.d). TRIPS and public health. Retrieved July 18 \& 22, 2019, from https://www.wto.org/english/tratop_e/trips_e/pharmpatent_e.htm.

World Trade Organization Analytical Index. (n.d.). Article 31 bis and the Annex to the TRIPS Agreement. Retrieved September 3, 2019, from http://www.wto.org/english/res_e/ publications_e/ai17_e/trips_art31_bis_oth.pdf.

Yong-Shik Lee, (2016). The long and winding road-Path towards facilitation of development in the WTO: Reflections on the Doha round and beyond. Law and Development Review, 9, 437-465. 